\begin{tabular}{l}
$\begin{array}{c}\text { Yanbu Journal } \\
\text { of }\end{array}$ \\
$\begin{array}{l}\text { Engineering } \\
\text { and Science }\end{array}$ \\
\hline ISSN: $1658-5321$
\end{tabular}$\quad$ Vol. 4, April $2012(1433 \mathrm{H})$

\title{
UTILIZATION OF WASTE CRUMBED RUBBER TIRE AS FINE CONCRETE AGGREGATE
}

\author{
Nadim A. Emira ${ }^{1}$ and Nasser S. Bajaba ${ }^{2}$ \\ 1 Yanbu Industrial College, PO Box: 30436, Yanbu Al-Sinaiyah 21477, Kingdom of Saudi Arabia, \\ On leave from Mechanical Design \& Production Department, Faculty of Engineering, Zagazig University, 44511 Zagazig, Egypt, \\ E-mail: nemira@yic.edu.sa \\ 2 Yanbu Industrial College, PO Box: 30436, Yanbu Al-Sinaiyah 21477, Kingdom of Saudi Arabia. \\ E-mail: bajaba@yic.edu.sa
}

\begin{abstract}
The use of solid wastes is not a new concept in concrete industries, but still in its early stages in the growing countries. There is a need to realize the value of recycling the crumbed rubber tires accumulated every year in Saudi Arabia and its use in concrete mixes. The objectives of the paper are to investigate the feasibility of incorporating tire crumb rubber as a replacement for natural mineral aggregates in concrete, study the influence of curing time on the compressive strength, and the engineering properties of concrete mix design with and without crumbed rubber. An important consideration has been acknowledged the development of rubberized concrete products which are feasible in terms of production and have some market potential. Three different concrete groups were prepared and tested in terms of compression. The mechanical test results demonstrated that the use of crumb rubber reduced all types of compressive strength. The different crumb rubber sizes have some influence on the mix and can be considered as structural light and moderate weight concrete.
\end{abstract}

Keywords: Concrete, Tire rubber, Rubberized concrete, Concrete workability

\section{INTRODUCTION}

\subsection{SOLID WASTES}

The waste problem considered as one of the most crucial problems facing the world as a source of the environmental pollution. Many of the wastes produced today will remain in the environment for hundreds, perhaps thousands of years. As the world population grows, the amount and type of waste being increased. The creation of non-decaying waste material, combined with a growing consumer population, has resulted in a waste disposable crisis; one solution to this crisis lies in recycling waste into useful products, continuously decreasing the number of landfills due to the reuse of these materials. The use of solid wastes is not a new concept in concrete industries, the possibility of using solid wastes as an aggregate in concrete has received increasing attention in recent years as a one promising solution to the escalating solid waste problem. For several decades industrial wastes were the bases of many concrete admixtures like fly ash and blast furnace slag which have been used as a pozzolanic material in concrete, both were used as aggregate and cemented materials [1]. Therefore from the environmental point of views, cement and concrete industries can be 
considered environmentally friendly. The use of fly ash, silica fumes and blast furnace slag in cement and concrete industries is helpful for both manufacturing of cemented products with improved durability and for reducing the disposal waste material [2].

\subsection{Problem of Rubber Wastes}

The waste is divided into Solid Waste, Liquid Waste and Gaseous Waste. There are lots of disposal ways for liquid and gaseous waste materials. Unlike solid waste materials such as PET bottles, papers, steel etc., can be recycled without affecting the environment. But there is no way to dispose some solid wastes such as waste tires. If the tire is burned, toxic products from the tire will damage the environment and thus creating air pollution. Since it is not a bio degradable material, this may affect the fertility of the soil and vegetation. Sometimes they may produce uncontrolled fire. Similarly, there is another challenge to the human society in the form of carbon dioxide emission and green house emission, which are considered as another type of waste, which is threatening the universe [3].

Waste rubber tires cause serious environmental problems all over the world. One of the potential means of utilizing the waste tires is to process this waste material for the protection of the environment and society. It is suggested to use this waste tires as an additive in Portland cement concrete (PCC) mixes for non-structural applications, which would partially help in solving this problem.

Big amounts of used rubber tires cumulate in the world each year - 275 million tons in the United States [4] and about 180 million tons in European Union [5].

One of the most popular methods is to pile used tires in landfills, as due to low density and poor degradation they cannot be buried in landfills [6]. These tires can also be placed in a dump, or basically piled in a large hole in the ground. However these dumps serve as a great breeding ground for mosquitoes and due to the fact that mosquitoes are responsible for the spread of many diseases, this becomes a dangerous health hazard [7]. In industry, higher amounts of rubber tire waste can be utilized as fuel, pigment soot, in bitumen pastes, roof and floor covers, and for paving industry [5, 8, and 9].

A possible solution of the problem is to incorporate the shredded rubber into concrete. As concrete becomes the most wildly used construction material in the world, the partial addition of the rubber tire particles into concrete would consume billions of scrap tires. In some application of concrete, it is desired that concrete should have low unit weight, high toughness and impact resistance. For Portland cement concrete, rubber from granulated tire may be used as an elastic aggregate modifying the brittle failure of concrete and increasing its ability to absorb high amount of energy before failure [10].

To improve the rubberized concrete strength, an abrasion resistance experiments were performed with specimens containing plain rubber aggregate or $\mathrm{NAOH}$-treated rubber [6]. The results show that the mass loss of specimens containing $\mathrm{NAOH}$-treated rubber was significantly lower than that of the specimens containing plain rubber aggregate. According to the authors, these results show the increased adhesion obtained by treatment of the rubber aggregate.

One such application that could use old rubber tires is rubberized concrete. Concrete can be made cheaper by replacing some of its fine aggregate with granulated rubber crumbs from used rubber tires. These granulated rubber crumbs are achieved through a process called continuous shredding, which is necessary to create crumbs small enough to 
replace an aggregate as fine as sand. Such kind of concrete is used in the manufacture of reinforced pavement and bridge structures have better resistance to frost and ice thawing salts [11, 8, and 12].

The replacement of aggregates with granulated rubber waste deteriorates mechanical properties of concrete [13 and 14]. The decrease of compressive strength of concrete after modification with rubber waste is explained by the more elastic and softer rubber particles compared to the sand particles [4, 13, and 14]. The second reason for concrete compressive strength reduction is significantly lower compressive strength of the crumbed rubber particles compared to the strength of concrete aggregates [15 and 16].

Deterioration of the mechanical properties of concrete with rubber additives is also explained by low adhesion among the rubber particles and cement matrix [5 and 17]. However, as observed in [18 and 19], there is a strong adhesion of contact zone between the rubber particles and cement mix; therefore this presumption should be rejected. Most compressive strength reduction was observed in concrete mixtures with adding $20 \%$ of tires rubber waste additive, [8 and 9].

Using rubber waste in concrete, less concrete modulus of elasticity is obtained $[4,18,20$, and 21] therefore modulus of elasticity is related to concrete compressive strength and the elastic properties of aggregates have substantial effect on the modulus of elasticity of concrete. The larger amount of rubber additives is added to concrete, the less modulus of elasticity is obtained [ 4 and 20].

\subsection{APPLICATIONS AND ADVANTAGES OF RUBBERIZED CONCRETE}

The rubberized concretes are affordable, cost effective and withstand more pressure, impact and temperature when compared it with conventional concrete. Studies show the CRC (crumb rubber concrete) specimens remained intact after failure (did not shatter) compared to a conventional concrete mix. Such behavior may be beneficial for a structure that requires good impact resistance properties. The impact resistance of rubberized concrete was higher, and it was particularly evident in concrete specimens aggregated with thick rubber [22]. Moreover, the unique qualities of rubberized concrete will find new areas of usage in highway constructions as a shock absorber, in sound barriers as a sound absorber and also in buildings as an earthquake shock-wave absorber. It reduces plastic shrinkage cracking and reduces the vulnerability of concrete to catastrophic failure.

Currently, the waste tire rubberized concrete is used in precast sidewalk panel, non-load bearing walls in buildings and precast roof for green buildings [23]. It can be widely used for development related projects such as roadways or road intersections, recreational courts and pathways, and skid resistant ramps [22]. With this new property it is projected that these concretes can be used in architectural applications such as nailing concrete, where high strength is not necessary, in wall panels that require low unit weight, in construction elements and Jersey barriers that are subject to impact, in rail road to fix rails to the ground [24].

Eldin, Topcu and Khatib [13, 24, and 25], graded the rubber size in their experimental works. They indicated that it was not possible to determine the gradation curve for their tire chips, as for normal aggregates, because they are elongated particles that range in size from about 10 to $50 \mathrm{~mm}$. The rubberized concrete tends to act as a large void and did not have a significant role in the resistance to applied external loading. Concrete containing rubber aggregate did not exhibit brittle failure under 
compression or split tension and was able to absorb a significant amount of plastic energy. Rubberized concrete can also be used in non load bearing members such as lightweight concrete walls, building facades, or other light architectural units, thus the waste tire modified concrete mixes could give a viable alternative to the normal weight concrete [25]. The tennis courts can now be poured in a single slab, eliminating 'section' lines which must be smoothed after curing. Roofing tiles and other concrete products can now be made lighter with Rubberized concrete [26]. It may also be used in runways and taxiways in the airport, industrial floorings and even as structural member.

\section{EXPERIMENTAL PROGRAM}

The experimental program demonstrates a detailed description of the mix of the raw materials. On the other hand the procedures of specimen's fabrication mixing and curing are illustrated. The different tests for the rubberized concrete are performed. The use of locally available materials from different sources in the Yanbu area was emphasized in this paper.

\subsection{Plain Portland Cement Concrete MiXes}

Concrete is a mixture of Cement, Sand (fine aggregate), small stone or gravel (Coarse aggregate) and water. It has many applications, from fence posts to motorway bases and, because of this; there are many different ratios for the constituents to be mixed.

This research will concentrate on a general purposed mix suitable for garden paths, fence posts, and shallow retaining wall foundations. A detail of this mixture proportions for this mixture except for the ready-mixed concrete is selected according to Saudi Building Code Committee [27].
The composition of cementitious material used in this mixture was $1 \mathrm{~kg}$ Cement, $4 \mathrm{~kg}$ Coarse aggregate $(12: 18 \mathrm{~mm}), 2 \mathrm{~kg}$ sand (Fine aggregate, 0: $3 \mathrm{~mm}$ ), and 0.55 water/cement ratio. These mixtures ingredients were used as a reference. Such mixes reflect the local design mixes used by the ready mix plants.

\subsection{TIRE COMPOSITION AND CHARACTERISTICS}

The average scrap automobile tire weighs approximately 20 pounds. The weight of the heavy truck and industrial tires can be ranging from 35 to several hundred pounds. All new car and light truck tires are steel belted radials. Eight to five percent of all scrap tires are passenger car or light truck tires, $14 \%$ are heavy truck tires, and the remaining $1 \%$ is a specialty tire ranging from aircraft tires to construction equipment tires [28]. A typical tire casing is composed of $83 \%$ carbon, $7 \%$ Hydrogen, $1.2 \%$ sulfur and $6 \%$ ash. Primary constituents of tires include polymers carbon black and softeners. The softeners are mostly composed of hydrocarbon oils, which in combination with polymers give the tire a very high heat resistance value [28].

The waste rubber used in this research was obtained from Saudi Rubber Products Co. (SARPC), Al-Khobar. They are either in 25 $\mathrm{kg}$ bags or jumbo bags (maximum of 1 ton) and are available in six different sizes; Powder $(0.01-0.5) \mathrm{mm},(0.5-2.0) \mathrm{mm}$, and (2.0-3.0) $\mathrm{mm}$.

The ratios of crumbed rubber that are used as a partial replacement for fine aggregates (sand) by volume are $(0 \%, 10 \%, 20 \%$, and $30 \%)$ for production of concrete. The volumetric content is always higher than its content by weight due to low specific gravity relative to the other ingredients. The crumbed rubbers that are used in this research are classified into three groups namely; powder $(0.01-0.5) \mathrm{mm}$, (0.5- 2.0) $\mathrm{mm}$, and (2.0-3.0) $\mathrm{mm}$. 


\subsection{APPLICATION OF RUBBERIZED CONCRETE}

Rubberized concrete can be used in applications where energy and impact attenuation is required due to its high flexibility. Unlike the control concrete that disintegrated when the peak load reached, the rubberized concrete underwent a considerable deformation without disintegration. In fact the control concrete sample broke into two halves after unloading, while the rubberized concrete sample kept its integrity and crack opening width was reduced and sometimes even closed.

Rubberized concrete, because of its light unit weight may also be suitable for architectural applications such as: Nailing concrete, False Facades, Stone backing, and Interior construction.

This suggests that rubberized concrete offer a great potential for using in sound/crash barriers, retaining structures and pavement structures if its strength is appropriate. However, more research is required on its significant uses before strong recommendations can be made [30].

\subsection{Testing the Compressive Strength of CONCRETE}

Concrete mixtures can be designed to provide a wide range of mechanical and durability properties to meet the design requirements of a structure. The compressive strength of concrete is the most common performance measure used by the engineer in designing buildings and other structures. Cylindrical specimens are tested in accordance with ASTM C 39, Standard Test Method for Compressive Strength of Cylindrical Concrete Specimens. A test result is the average of three standard-cured strength specimens made from the same concrete sample and tested at the same age.

\subsection{Casting and Curing}

Cylindrical specimens of $(150 \times 300) \mathrm{mm}$ in size were specified. The smaller specimens tend to be easier to make and handle in the field and the laboratory. All laboratory batches of concrete were cast inside the laboratory of, OSAIMI ENGINEERING OFFICE (Yanbu Al Sinaiyah), in a small capacity drum mixer to check if silica fume was properly mixed during initial mixes. The mixing, casting, and curing conformed to ASTM C192 [29].

The cylindrical samples were cast in steel molds to eliminate any effect that could result from plastic or cardboard molds. The standard size cylindrical specimens were cast in two layers with each layer vibrated in a vibrating table for 35 to 45 seconds.

The specimens were de-molded after $24 \mathrm{hr}$, and then subjected for 28 days to standard moist curing by immersing them in curing tanks containing lime saturated water at $23^{\circ} \mathrm{C}$. The specimens of all groups are tested after different curing time namely; $7,14,21$, and 28 days.

\section{RESULTS AND DISCUSSIONS}

\subsection{Test Procedure}

After needed materials were prepared with specifications and concrete mix design according to Saudi Building Code Committee [27], laboratory specimens were made in three sets. To obtain the reliable result, three samples were made and tested for each type of test.

First group: In this group four different types of samples were used, namely; control concrete samples, rubberized concrete samples with $10 \%, 20 \%$, and $30 \%$ partial replacement for fine aggregates (sand) by volume. The size of $(0.01-0.5) \mathrm{mm}$ of crumbed rubber was used for this group. 
The second and the third groups contain the previous four different types of samples of the first group, and also sizes of (0.5-2.0) $\mathrm{mm}$ and (2.0-3.0) $\mathrm{mm}$ crumbed rubber were used for both second and third group respectively.

The ratio of the composition of material used for the mixes were $1 \mathrm{~kg}$ Cement, $4 \mathrm{~kg}$ Coarse aggregate $(12: 18 \mathrm{~mm}), 2 \mathrm{~kg}$ sand (Fine aggregate, $0-3 \mathrm{~mm}$ ), and 0.55 water/cement ratio. These ratios were kept constant for all concrete mixes. The volumetric content is always higher than its content by weight due to low specific gravity relative to the other ingredients. At the age of 7, 14, 21, and 28 days the specimens were taken out from the curing tank.

The compressive strength was measured in compliance with ASTM C39 standard test method [29]. To perform compression tests a $3000 \mathrm{kN}$ Auto Comp 2 compression machine manufactured by Controls was used. The load accuracy of this machine is $\pm 1 \%$. The machine used has a high stiffness frame with four pre-stressed columns to ensure maximum rigidity and stability and is suitable for cylinder and cube testing.

\subsection{Test RESUlts AND DisCussions}

During the course of this study, over 148 specimens from a medium strength mix were used. This mixture was prepared and tested in OSAIMI ENGINEERING OFFICE (Yanbu Al Sinaiyah). The three sets of crumbed rubber sizes $(0.01-0.5),(0.5-2)$, and (2.0$3.0) \mathrm{mm}$ were used in the concrete mix. After $7,14,21$, and 28-day curing time, the control concrete and the rubberized samples of $150 \times$ $300 \mathrm{~mm}$ were tested for compressive strength. Table 1 shows the effects of crumb rubber on concrete compressive strength during different curing times of the three sets.

TABLE 1: COMPRESSIVE STRENGTH OF THREE SETS FOR CONTROL AND RUBBERIZED SPECIMENS WITH PARTIAL VOLUME REPLACEMENT 10\%, 20\%, 30\% AND DIFFERENT RUBBER SIZE.

\begin{tabular}{|c|c|c|c|c|c|c|c|c|c|}
\hline \multirow{3}{*}{ Samples } & \multirow{3}{*}{\multicolumn{5}{|c|}{$\begin{array}{c}\text { Mixture Content } \\
\text { The composition of material used }(\mathrm{kg})\end{array}$}} & \multicolumn{4}{|c|}{ Compressive strength (MPa) } \\
\hline & & & & & & \multicolumn{4}{|c|}{ Curing time (days) } \\
\hline & & & & & & 7 & 14 & 21 & 28 \\
\hline \multirow{2}{*}{ 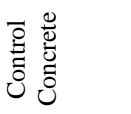 } & \multicolumn{5}{|c|}{ Cement : Sand : Aggregate : Water } & \multirow{2}{*}{21.2} & \multirow[b]{2}{*}{23.3} & \multirow{2}{*}{24.0} & \multirow[b]{2}{*}{25.5} \\
\hline & & & 2 & & 0.55 & & & & \\
\hline \multirow{4}{*}{ 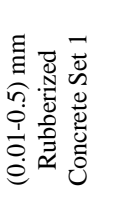 } & \multicolumn{5}{|c|}{ Cement : Sand : rubber : Aggregate : Water } & \multirow[b]{2}{*}{20.3} & \multirow[b]{2}{*}{21.9} & \multirow[b]{2}{*}{23.0} & \multirow[b]{2}{*}{24.0} \\
\hline & 1 & 1.8 & 0.116 & 4 & 0.55 & & & & \\
\hline & 1 & 1.6 & 0.216 & 4 & 0.55 & 18.7 & 20.2 & 21.2 & 22.1 \\
\hline & 1 & 1.4 & 0.311 & 4 & 0.55 & 16.9 & 17.8 & 18.5 & 19.0 \\
\hline \multirow{4}{*}{ 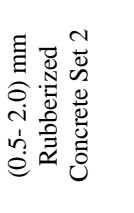 } & \multicolumn{5}{|c|}{ Cement : Sand : rubber : Aggregate : Water } & \multirow[b]{2}{*}{20.1} & \multirow[b]{2}{*}{21.6} & \multirow[b]{2}{*}{22.4} & \multirow[b]{2}{*}{23.4} \\
\hline & 1 & 1.8 & 0.1373 & 4 & 0.55 & & & & \\
\hline & 1 & 1.6 & 0.2727 & 4 & 0.55 & 18.5 & 19.5 & 20 & 21.1 \\
\hline & 1 & 1.4 & 0.4072 & 4 & 0.55 & 16.5 & 17.0 & 17.6 & 18.0 \\
\hline \multirow{4}{*}{ 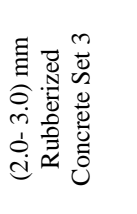 } & Cem & :San & : rubber & ggr & te : Water & \multirow[b]{2}{*}{19.7} & \multirow[b]{2}{*}{20.8} & \multirow[b]{2}{*}{21.9} & \multirow[b]{2}{*}{23.5} \\
\hline & 1 & 1.8 & 0.1442 & 4 & 0.55 & & & & \\
\hline & 1 & 1.6 & 0.2800 & 4 & 0.55 & 17.3 & 18.0 & 18.9 & 20.3 \\
\hline & 1 & 1.4 & 0.4562 & 4 & 0.55 & 14.65 & 15.4 & 16.0 & 16.3 \\
\hline
\end{tabular}




\subsubsection{Effect of curing time}

For the three sets and as a result of increasing curing time, Fig. 1 shows the effect of curing time of both control and rubberized samples on compressive strength. As shown in the figure, the upper sold data line represent curing time of the control sample. For the other broken lines, the rubberized samples of the three sets are presented with the same partial replacement ratios of fine aggregates (sand) by volume $(10 \%, 20 \%$, and $30 \%)$. As evident in the figure, the slopes of the three rubberized sets are equal. Therefore, and for all the specimens in the three sets, increasing the curing time tends to increasing of the compressive strength.

\subsubsection{Effect on compressive strength}

The relationship between the percentage of crumb rubber content and the reduction in compressive strength is presented in Fig. 2. It is evident that the use of crumb rubber reduced the compressive strength. As expected, the higher the rubber content in the mix, the higher the reduction in compressive strength.

\subsubsection{Effect on workability and unit weight}

The values of partial replacement of the crumb rubber content, the mix proportions and the weight of one specimen $(150 \times 300 \mathrm{~mm})$ are recorded in table 2 . It demonstrates the effect of changing the percentage of crumb rubber over weight of the specimens. It also demonstrates that increasing the percentage of the rubber in the specimens would reduce the weight of the specimens, and the mix still produced a workable mix with comparison to the control mix.

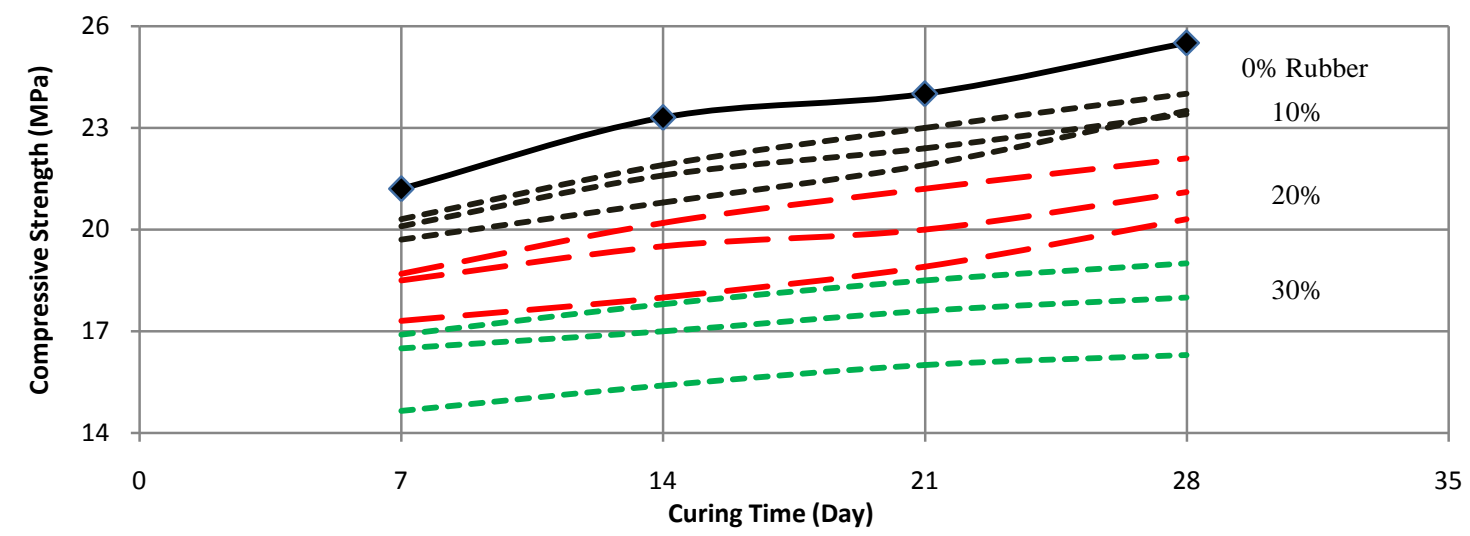

Fig. 1. Effect of curing time of the three sets on both control and rubberized concrete specimens of crumbed rubber sizes $(0.01-0.5),(0.5-2)$, and $(2.0-3.0) \mathrm{mm}$ respectively

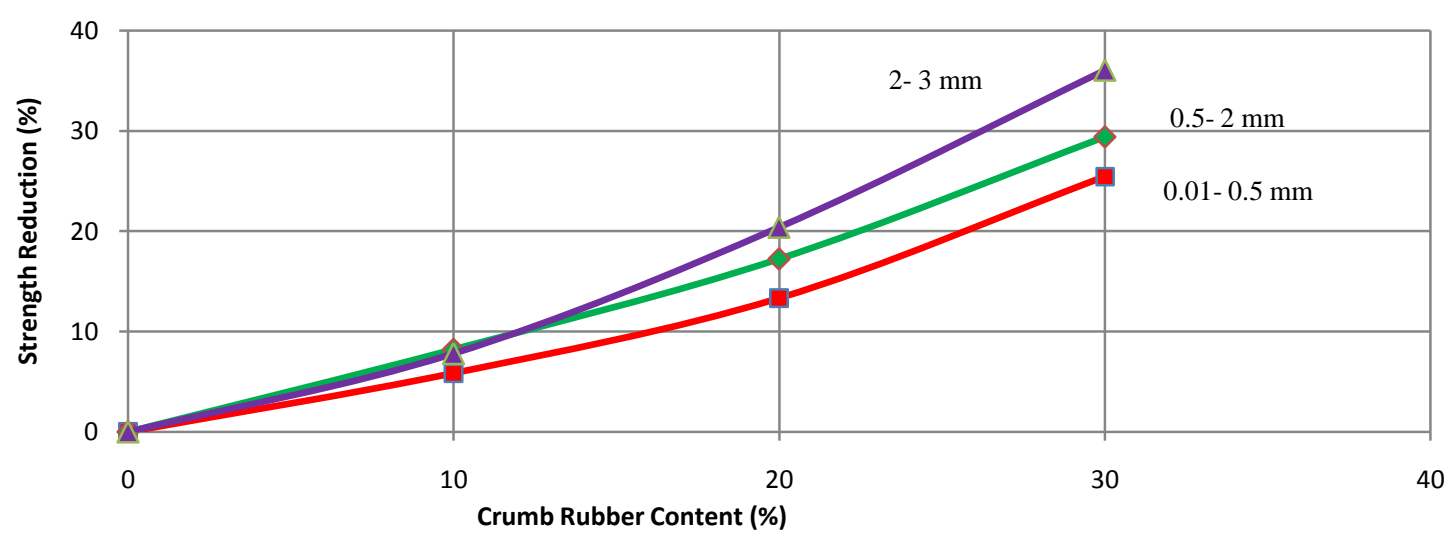

Fig. 2. Strength reductions for the three tested sets 
Fig. 3 shows that the weights of all the three rubberized concrete specimens are reduced as the crumbed rubber ratios and sizes are increased. In other words, at $10 \%$ the decrease in weight was $0.17,0.25$, and $0.52 \mathrm{~kg}$ for the sizes (0.01-0.5), (0.5-2.0), and (2.0-3.0) $\mathrm{mm}$ respectively. At $20 \%$ the decrease was $0.57,0.67$, and $0.82 \mathrm{~kg}$ for the same sizes. And for $30 \%$ the decrease was $0.72,0.92$, and $1.07 \mathrm{~kg}$ also for the same sizes.
Therefore, for sizes from 0.01 to $2.0 \mathrm{~mm}$ and up to $30 \%$ partial replacement it can be considered as structural light weight concrete. On the other hand, for sizes from (2.0 to 3.0) $\mathrm{mm}$, and up to $30 \%$ partial replacement it can be considered as moderate strength concrete. Table 3 illustrates that the required compressive strength for the different applications of the structural light weight concrete (LWC) as specified by Neville [32].

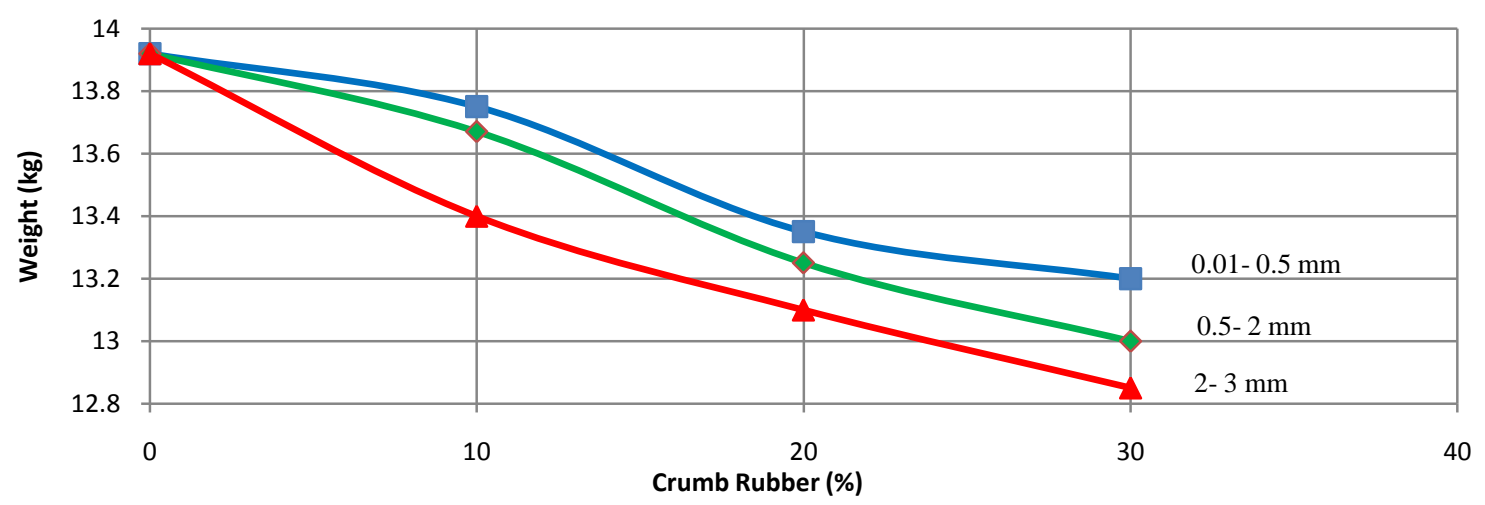

Fig. 3. Effect of different partial replacement of crumbed rubber at different sizes on the weight of three sets specimens

TABLE 2: MiX PROPORTIONS OF CONTROL AND FRESH RUBBERIZED CONCRETE PROPERTIES (28 DAYS)

\begin{tabular}{|c|c|c|c|c|c|}
\hline \multirow{2}{*}{$\begin{array}{c}\text { Crumb rubber } \\
\text { content }(\%)\end{array}$} & \multicolumn{4}{|c|}{ Mix proportions $\left(\mathrm{kg} / \mathrm{m}^{3}\right.$ for one specimen $\left.150 \times 300 \mathrm{~mm}\right)$} & \multirow{2}{*}{$\begin{array}{l}\text { Weight of one } \\
\text { specimen }(\mathrm{kg})\end{array}$} \\
\hline & Rubber & Cement & $\begin{array}{c}\text { Coarse } \\
\text { Aggregates }\end{array}$ & Fine Aggregates & \\
\hline
\end{tabular}

\begin{tabular}{|c|c|c|c|c|c|c|}
\hline \multicolumn{7}{|c}{ First Set with crumbed rubber size (0.01 - 0.5) mm } \\
\hline 0 & 1.25 & 2.25 & 9 & 4.50 & 0 & $\mathbf{1 3 . 9 2}$ \\
\hline 10 & 1.25 & 2.25 & 9 & 4.05 & 0.116 & $\mathbf{1 3 . 7 5}$ \\
\hline 20 & 1.25 & 2.25 & 9 & 3.60 & 0.216 & $\mathbf{1 3 . 3 5}$ \\
\hline 30 & 1.25 & 2.25 & 9 & 3.15 & 0.311 & $\mathbf{1 3 . 2 0}$ \\
\hline
\end{tabular}

Second Set with crumbed rubber sizes $(0.5-2) \mathrm{mm}$

\begin{tabular}{|c|c|c|c|c|c|c|}
\hline 0 & 1.25 & 2.25 & 9 & 4.50 & 0 & $\mathbf{1 3 . 9 2}$ \\
\hline 10 & 1.25 & 2.25 & 9 & 4.05 & 0.1373 & $\mathbf{1 3 . 6 7}$ \\
\hline 20 & 1.25 & 2.25 & 9 & 3.60 & 0.2727 & $\mathbf{1 3 . 2 5}$ \\
\hline 30 & 1.25 & 2.25 & 9 & 3.15 & 0.4072 & $\mathbf{1 3 . 0 0}$ \\
\hline
\end{tabular}

Third Set with crumbed rubber sizes $(2.0$ - 3.0) $\mathrm{mm}$

\begin{tabular}{|l|l|l|l|l|l|l|}
\hline 0 & 1.25 & 2.25 & 9 & 4.50 & 0 & $\mathbf{1 3 . 9 2}$ \\
\hline 10 & 1.25 & 2.25 & 9 & 4.05 & 0.1442 & $\mathbf{1 3 . 4 0}$ \\
\hline 20 & 1.25 & 2.25 & 9 & 3.60 & 0.2800 & $\mathbf{1 3 . 1 0}$ \\
\hline 30 & 1.25 & 2.25 & 9 & 3.15 & 0.4562 & $\mathbf{1 2 . 8 5}$ \\
\hline
\end{tabular}


Due to the low specific gravity of the rubber, the concrete with crumb rubber can be classified as light weight concrete. This can also be supported by the work conducted by Pierce and Blackwell [32].

The minimum strength required for structural light weight concrete is $17 \mathrm{MPa}$, as shown in Table 3. In this study and from Table 1, using $30 \%$ crumb rubber of all the three sizes can achieve an average strength of $17.76 \mathrm{MPa}$. Therefore, the rubberized concrete containing up to $30 \%$ crumb rubber can be used in light weight structural concrete. The second category given in Table 3, requiring compressive strength of $7-17 \mathrm{MPa}$ for moderate concrete can be also achieved with increasing the partial replacement of the rubber up to $30 \%$ and increasing the sizes up to $3 \mathrm{~mm}$.

TABle 3: PRACTICAL RANGE OF CATEGORIES OF LIGHT WEIGHT CONCRETE (NEVILLE [31])

\begin{tabular}{|l|l|l|}
\hline \multicolumn{1}{|c|}{ Categories } & \multicolumn{1}{|c|}{$\begin{array}{c}\text { Density range } \\
\left(\mathbf{k g} / \mathbf{m}^{3}\right)\end{array}$} & \multicolumn{1}{|c|}{$\begin{array}{c}\text { Minimum } \\
\text { strength (MPa) }\end{array}$} \\
\hline $\begin{array}{l}\text { Structural light } \\
\text { weight concrete }\end{array}$ & $1350-1900$ & \multicolumn{1}{|c|}{17} \\
\hline $\begin{array}{l}\text { Moderate strength } \\
\text { concrete }\end{array}$ & $1900-800$ & $7-17$ \\
\hline $\begin{array}{l}\text { Low density } \\
\text { concrete }\end{array}$ & $300-800$ & $\begin{array}{l}\text { Used for non- } \\
\text { structural purposes } \\
\text { (insulation panel, } \\
\text { pavements, blocks, } \\
\text { etc.) }\end{array}$ \\
\hline
\end{tabular}

\section{CONCLUSION}

The results of this study indicate that there is a great potential for the utilization of waste tires in concrete mixes in several percentages, including $10 \%, 20 \%$, and $30 \%$. Based on these results, the following can be concluded:

- For all the specimens, increasing the curing time tends to increase the compressive strength for all crumbed rubber sizes
- The rubberized concrete mix using recycled tires agreed with the values of compressive test for light and moderate weight structural concrete as shown in Table 3

- Although the strength of rubberized concrete is reduced with an increase in the rubber content, its lower unit weight meets the criteria of light weight concrete that fulfill the strength requirements in Table 3. Although it is not recommended to use this rubberized concrete in structural elements where high strength is required, it can be used in many other construction work like partition walls, road barriers, pavements, sidewalks, etc. which are in high demand in the construction industry

- The amount of waste tires being accumulated in third world countries have created a big challenge for their disposal because of long life decomposition time, thus obliging the authorities to invest in facilitating the use of waste tires in concrete, as the use of concrete is fundamental to the booming construction industry in these countries

\section{ACKNOWLEDGEMENTS}

The author would like to acknowledge the support of the Saudi Rubber Products Co. (SARPC) Al-Khobar, for supplying the recycled tire rubber. On other hand the author would like to thank Osaimi Engineering Office, Yanbu Al Sinaiyah, for their technical assistance in the laboratory.

\section{REFERENCES}

[1] Hakkinen, T. and Kronlof, A. Environmental Effect of Building Materials, VTT Tiedotteita 1591, Espoo, Technical Research Center of Finland, 1994, pp 25-61. 
[2] Mehat, P. K., Bringing the Concrete Industry Into a New Era of Sustainable Development, Mario Collepardi Symposium on Advances in Concrete Science and Technology, 1997, pp 49-67.

[3] Senthi Kumaran, G. Nurdin Mushule and Lakshmipathy, M., A Review on Construction Technologies that Enables Environmental Protection: Rubberized Concrete, American Journal of Engineering and Applied Science, Vol.1 (1), 2008, pp 40 - 44.

[4] Papakonstantinou, C. G., Tobolski, M. J. Use of Waste Tire Steel Beads in Portland Cement, Concrete Cement and Concrete Research, Vol.36 (9) , 2006, pp 1686 - 1691.

[5] Silvestravičiūtè, I., Šleinotaitė-Budrienė, L., Possibility to Use Scrap Tires as an Alternative Fuel in Cement Industry Environmental Research, Engineering and Management, Vol.3 (21), 2000, pp 38-48.

[6] Segre, N., Joekes, I. Use of Tire Rubber Particles as Addition to Cement Paste, Cement and Concrete Research 30 (9), 2000, pp 1421 - 1425.

[7] Shuaib, Ahmad, Fedroff, David, Sayas, Banu Zeynep, and Freeze-Thaw Durability of Concrete With Ground Waste Tire Rubber, Transportation Research Record 1574, 1997.

[8] Skripkiūnas, G., and Grinys, A. Using Tires Rubber Waste for Modification of Concrete Properties Building and Architecture. Proceedings of Conference, Kaunas, 2005, pp 132 - 137.

[9] Skripkiūnas, G., and Grinys, A. Using Tires Rubber Waste for Modification of Concrete Properties Science Days, Dnepropetrovsk, 2005, pp 5-40.

[10] Dimitrios, G. G., and Al-Hosain Ali, NonDestructive Evaluation of Rubber Modified Concrete, Infrastructure Condition Assessment, Rubber Modified Concrete Evaluation, Polytechnic University, Six Metro-tech, Brooklyn, NY, 11201, 1995, pp 111-120.

[11] Kerševičius, V. Rubber Waste - Raw Materials for Building: Technical and Economical Aspects of Utilization, Environmental Research, Engineering and Management, Vol.3 (21), 2002, pp $72-77$.

[12] Skripkiūnas, G., Grinys, A., Using Tires Rubber Waste for Modification of Concrete Properties, Science Days, Dnepropetrovsk, 2005, pp 5-40.
[13] Eldin, N. N., Senouci, A. B., Rubber Tire Particles as Concrete Aggregate, Journal of Material Civil Engineering ASCE Vol.5 (4), 1993, pp 478 - 496.

[14] Lee, B. I., Burnett, L., Miller, T., Postage, B., Cuneo, J., Tire Rubber Cement Matrix Composites, Journal of Material Science Letter Vol.12 (13), 1993, pp $967-968$.

[15] Eldin, N. N., Senouci, A. B., Measurement and Prediction of the Strength of Rubberized Concrete, Cement \& Concrete Composites 18, 1996, pp 135- 139 .

[16] Sheikin, E., Schekovskyj, J. V., Bruser, M. I., Properties and Composition Cement Based Concrete, Moscow: Stroiizdat, 1979, pp 344.

[17] Li, G., Stubblefield, M. A., Garrick, G., Eggers, J., Abadie, Ch., Huang, B., Development of Waste Tire Modified Concrete, Cement and Concrete Research Vol.34 (12), 2004, pp 2283 - 2289.

[18] Hernandez-Olivares, F., Barluenga, G., Bollati, M., Witoszek, B. Static and Dynamic Behavior of Recycled Tire Rubber-filled Concrete, Cement and Concrete Research Vol.32 (10) , 2002, pp 1587- 1596.

[19] Skripkiūnas, G., Grinys, A., Daukšys, M. Using Tires Rubber Waste for Modification of Concrete Properties, Sustainable Construction Materials and Technologies International Conference Coventry, Taylor \& Francis Group, London, 2007.

[20] Güneyisi, E., Gesoglu, M., Özturan, T. Properties of Rubberized Concretes Containing Silica Fume, Cement and Concrete Research Vol.34 (12), 2004, pp 2309 - 2317.

[21] Bignozzi, M. C., Sandrolini, F. Tyre Rubber Waste Recycling in Self-compacting Concrete Cement and Concrete Research Vol.36 (4), 2006, pp $735-739$.

[22] Kamil E. Kaloush, P.E. George, B. Way, P.E. Han Zhu, Properties of Crumb Rubber Concrete, Journal of the Transportation Research Board under the category Materials and Construction, 2005, pp 8-14.

[23] Fuminori Tomosawa, Takafumi Noguchi and Masaki Tamura, The way concrete recycling should be. Journal of Concrete Technology, Vol.3, 2005, pp 3-16.

[24] Topcu, I.B., The Properties of Rubberized Concrete, Cement. Concrete Research, Vol.25 (2) , 1995, pp 304-310. 
[25] Khatib, Z.K. and F.M. Bayomy, Rubberized Portland cement concrete, Journal of Material in Civil, Engineering ASCE, Vol.11 (3) , 1999, pp 206-213.

[26] Kamil Kaloush, Doug Carlson, George Way and Mark Belshe, Crumb Rubber Concrete-Precast of the future? 2004.

http://www.precast.org/publications/solutions/cr umb_rubber.htm

[27] Saudi Building Code Committee, First Edition: January 2007. ISBN: 9960-9883-5-X, www.sbcnc.gov.sa

[28] Lund, H. F., Recycling Handbook, New York, USA, McGraw Hill, Inc., USA 1993.

[29] ASTM C 31, C 39, C192, C 617, C 1077, C 1231, Annual Book of ASTM Standards, Volume 04.02, ASTM, West Conshohocken, PA, ww.astm.org

[30] Fatuhi, N. and Clark, N., Cement Based Materials Containing Tire Rubber, Construction Building Materials, Vol.10 (4), 1996, pp 229236.

[31] Neville, A.M., Properties of Concrete. Addison Wesley Longman limited, England, 1995.

[32] Pierce, C.E., and Blackwell, M.C., Potential of scrap tire rubber as lightweight aggregate in flowable fill, Waste Management, Vol.23, 2003, pp197-208. 


\title{
إستعمال مطحون الإطاراتِ المطاطيةِ كبديل للإضافات الناعمة بالخرسانة
}

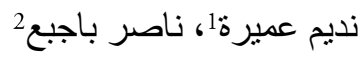 \\ 1 كلية ينبع الصناعية، ينبع، المملكة العربية السعودية

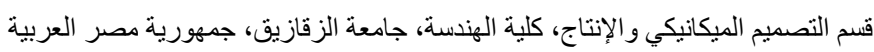

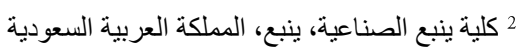

\begin{abstract}
إن إستعمال النفايات الصلبة لبس بالمفهوم الجديد في الصناعات الخرسانية، غير أنّه بعد في مراحله المبكرة في البلدان النامية. إن هناك حاجة إلى أن نتحقّق من قيمة إعادة تدوير الإطاراتِ المطاطيةِ المطحونة في المملكة العربية السعودية فى تز ايد متتامى ويَحتاجُ لإدْر الك قيمةِ إستخدامه فى عمليات المزج الخرساني. من أهدافَ هذا البحث هو التحرى عن كيفية إستخدام المطاط المطحون للإطارات المستهلكة ليحل كبديل للتجمعاتِ المعدنية. الطبيعية في الخرسانةِ، ودر اسة تأثير الزمن على خاصية مقاومة الأنضغاط، ووكذلك أيضا دراسة كذلك أيضا تحرّى إستخدام الخليط المطاطي المطحون في تصميمٍ الخلطة الخرسانيةِ ومعرفة بعض من الخواص الهندية للمزيج الخرساني فى حالة وجود و عدم وجود المطاط المطحون. كذلك أيضا دراسة تأثير الزمن على خاصية مقاومة الأنضغاط فى حالة وجود و عدم وجود المطاط المطحون. كنلك أيضا نَتحرّى إستخدام الخليط المطاطي المطحون في تصميمٍ الخلطة الخرسانيةِ ومعرفة بعض الخواص الهندسية للمزيج الخرساني. ويعتبر ذلك الإعتبار مهم لتطويرَ المُنتَجاتِ الخرسانيةِ المُمَطَّطةِة التى بمكن أن تنتج ولها بَغْض الإستخدامات فى السوقِ. تم إعداد ثلاثة مجموعات مختلفة لإختبار مقاومة الأنضغاط. وقد بيَنتنْ نَتائجُج الإختبارِ الميكانيكية بأنَّ إستعمالُ المطاط المطحون للخرسانة يخفض مقاومة الأنضغاط. كذلك ايضا فإن لمقاسات المطاط المطحون نأثير على تصنيف وزن الخلطة الأسمنتية كخفيفة ومتوسطة.
\end{abstract}

